\title{
Fish Production, Water Quality and Bacteriological Parameters of Koi Carp Ponds Under Live-food and Manure Based Management Regimes
}

\author{
Prithwiraj Jha $^{1, *}$, Sudip Barat ${ }^{1}$, Chitta R. Nayak ${ }^{2}$ \\ (1. Department of Zoology, University of North Bengal, Siliguri 734013, District Darjeeling, West Bengal, India; \\ 2.Computer Centre, University of North Bengal, Siliguri 734 013, District Darjeeling, West Bengal, India)
}

\begin{abstract}
To test the effectiveness of introducing live zooplankton against direct manuring in ornamental fish ponds upon their survival and production, larvae of koi carp, Cyprinus carpio L., were cultured for 11 weeks in earthen ponds maintained according to four management regimes: (1) live zooplankton fed to carp larvae (LF); (2) direct fertilization with poultry manure (PM); (3) direct fertilization with cowdung (CD); and (4) a control treatment (C). There were three replicates for each treatment. The growth of heterotrophic bacteria and pathogenic microorganisms like Aeromonas sp. and Pseudomonas sp. were also examined in response to pond management. Values of dissolved oxygen were significantly higher $(P<0.05)$ in the water of LF ponds, compared to other treatments, while the PM and CD treatments recorded were significantly higher $(P<0.05)$ values of $\mathrm{PO}_{4}-\mathrm{P}, \mathrm{NH}_{4}-\mathrm{N}, \mathrm{NO}_{3}-\mathrm{N}, \mathrm{NO}_{2}-\mathrm{N}$, specific conductivity, alkalinity, and BOD, compared to the LF and C treatments. The percentages of organic carbon and total nitrogen in the bottom sediments were higher in the PM and CD treatments compared to LF $(P<0.05)$. Average counts of heterotrophic bacteria in the water of PM and CD ponds were significantly higher than other treatments $(P<0.05)$. The development of Aeromonas sp. and Pseudomonas sp. were significantly higher $(P<0.05)$ in the PM and CD treatments. Weight gain of koi carp stocked in LF was significantly higher $(P<0.05)$ than that of fish in the other treatments. There was a significant difference in the survival rate of koi carp among the treatments ranging from $67.21 \%$ in $\mathrm{C}$ to $90.11 \%$ in LF. The results suggest that raising koi carp larvae in ponds and feeding them exogenously with zooplankton would support high rates of survival and production through maintenance of better water quality and greater abundance of zooplankton in the system. Significantly lower abundance of Aeromonas sp. and Pseudomonas sp. in the LF treatment considerably lowered any possibility of occurrence of bacterial disease.
\end{abstract}

Key words: Koi carp ponds; Cyprinus carpio L.; Management; Growth; Water quality; Bacteriology

\section{活体和施肥管理体系下锦鲤池塘产量、水质及细菌学参数}

\author{
Prithwiraj Jha $^{1, *}$, Sudip Barat ${ }^{1}$, Chitta R. Nayak ${ }^{2}$ \\ (1. Department of Zoology, University of North Bengal, Siliguri 734013, District Darjeeling, West Bengal, India; \\ 2.Computer Centre, University of North Bengal, Siliguri 734 013, District Darjeeling, West Bengal, India)
}

摘要: 为探讨在观赏池塘中的投放浮游动物以及直接投放动物粪便对锦鲤（Cyprinus carpio L.) 的生长及 产量的影响, 在池塘中进行了为期 11 周的实验。实验按如下四种管理系统进行处理: 1. 给幼体锦鲤投喂浮游动 物饲料(LF 组); 2. 直接投放家禽粪便( PM 组); 3. 直接投放牛粪(CD 组); 4. 不投放任何食物, 仅进行常规管理(C 组)。每组实验重复三次。同时检测非自养细菌及致病微生物(如: Aeromonas sp. 和 Pseudomonas sp.)的生长状 况, 以此了解池塘的管理状况。在 LF 组中, 其水体含氧量较高, 与其它组相比具显著差异 $(P<0.05)$ 。而 $P M$ 、 $\mathrm{CD}$ 组与 $\mathrm{LF} 、 \mathrm{C}$ 组比较, 在 $\mathrm{PO}_{4}-\mathrm{P}, \mathrm{NH}_{4}-\mathrm{N}, \mathrm{NO}_{3}-\mathrm{N}, \mathrm{NO}_{2}-\mathrm{N}$ 的关系, 导电率、碱度以及生化需氧量等较高, 且 差异显著 $(P<0.05)$, 在池塘底部淤泥中的总氮量及有机碳百分率方面 PM、CD 与 LF 组相比, 具有显著差异 $(P$ $<0.05 ） 。 \mathrm{PM}$ 与 CD 组与其它组相比在池塘中的非自养细菌（Aeromonas sp. 和 Pseudomonas sp.) 的繁殖率较高, 皆具显著差异 $P<0.05)$ 。 LF 组中锦鲤的体重增长率较其它组高 $(P<0.05)$ 。锦鲤幼体在 C 及 LF 组中的成活率分别

Received date: 2007-10-11; Accepted date: 2007-12-05

* Corresponding author（通讯作者）, E-mail: jhakingshuk@rediffmail.com

收稿日期：2007-10-11; 接受日期：2007-12-05 
为: $67.21 \%$ 和 $90.11 \%$ 。结果提示: 提高锦鲤幼体的存活率及其产量可通过对水质的管理(即保持优良水质)及提高 池塘中浮游生物丰富度加以获得。值得注意的是：LF 组中非自养细菌（Aeromonas sp. 与 Pseudomonas sp.）比率 的过低将导致细菌性疾病的发生。

关键词: 锦鲤池塘; 鲤鱼.; 管理; 生长; 水质; 细菌学

中图分类号：Q959.468; Q17 文献标识码：A 文章编号：0254-5853（2008）02-0165-09

The purpose of pond fertilization is to augment fish production through autotrophic and heterotrophic pathways. Organic manures, being less expensive compared to chemical fertilizers, contain almost all the essential nutrient elements (Jana et al, 2001), and are traditionally applied to fish ponds to release inorganic nutrients which stimulate the growth of plankton (Wurts, 2000; Ansa \& Jiya, 2002; Kadri \& Emmanuel, 2003). The available organic pool in manured ponds is usually duplicated everyday via bacterial production (Schroeder, 1987). Heterotrophic microorganisms, necessitating some organic sources of carbon in addition to inorganic forms for growth, have a significant role in the decomposition of organic matter and production of particulate food materials from dissolved organics (Jana \& De, 1990). However, the role of heterotrophic bacteria in the food web and its effect on fish yield are poorly documented (Moriarty, 1987). According to our knowledge, there have been no studies on the abundance of heterotrophic bacteria in ornamental fish ponds in India.

Another aspect of pond management that has increasingly gained importance in the past decade is water quality problems in ornamental fish ponds. Pond fertilization using high amounts of animal wastes are known to have caused noticeable harm to the environment (Quines, 1988), by proliferating the growth of pathogenic bacteria like Aeromonas sp. and Pseudomonas sp. in the water-body (Hojovec, 1977; Sugita et al, 1985a; Jinyi et al, 1987). Freshwater fish in Indian ponds commonly suffer from bacterial diseases such as various kinds of skin ulcerations, albinoderma, erythroderma, furunculosis, and verticle-scale disease, primarily caused by Aeromonas sp. and Pseudomonas sp. (Das, 2004).

Organic manuring also leads to severe depletion of dissolved oxygen, high biological and chemical oxygen demand, and high ammonia levels (Boyd, 1982), leading to stress in cultured fish (Parker, 1986). Since ornamental fish ponds in India are much smaller compared to other aquaculture ponds (measuring about 7 $\mathrm{m} \times 20 \mathrm{~m}$, with an average depth of $0.6-1.0 \mathrm{~m}$ ), there are more opportunities to control environmental conditions in ornamental fish ponds by employing proper management techniques. Introduction of live zooplankton has been investigated as a practicable alternate to pond fertilization for increasing ornamental fish yields while avoiding water quality deterioration (Jha \& Barat, 2005a; Jha et al, 2006; Jha et al, 2007). However, there is a paucity of documentation pertaining to bacteriological parameters of ornamental fish ponds, particularly those under live-food and manure based management regimes.

The objective of the present study was to investigate the growth responses of heterotrophic bacteria, along with the development of Aeromonas sp. and Pseudomonas sp. in ornamental fish ponds maintained under live-food and manure based management regimes, for the culture of koi carp, Cyprinus carpio L.

\section{Materials and methods}

The koi carp used in this study were the offspring of 40 pairs of Asagi, Bekko, Kohaku and Showa koi types and were obtained from a local fish farm (Rainbow ornamentals, Jalpaiguri, India). The fish were acclimatized for seven days before the experiment. The study was conducted in twelve earthen ponds (capacity: 59600 L each) in Raninagar village, Jalpaiguri, India. About two week old koi carp larvae $(0.12 \pm 0.007 \mathrm{~g})$ were stocked in the experimental ponds and maintained at a density of 0.3 fish/L, as optimized in an earlier experiment (Jha \& Barat, 2005b). Fish were cultured for 11 weeks (02 June to 18 August, 2004) according to one of the four management regimes: (1) live zooplankton was introduced into the ponds by transferring about 1000 $\mathrm{L}$ of plankton water everyday form a series of ponds maintained separately for culturing live plankton (LF); (2) direct fertilization with poultry manure at $0.26 \mathrm{~kg} / \mathrm{m}^{3}$, every 10 days (PM); (3) direct fertilization with cow dung at $0.26 \mathrm{~kg} / \mathrm{m}^{3}$, every 10 days (CD); and (4) a control treatment $(\mathrm{C})$, where a commercial pellet diet was used as feed.

There were three replicates for each treatment. The ponds used for culturing plankton were maintained separately according to similar management condition as applied to the PM ponds. The application rate of 0.26 
$\mathrm{kg} / \mathrm{m}^{3}$, every 10 days, for both the poultry and cow manures, were standardized in an earlier experiment (Jha et al, 2004). A single layer of nylon bird netting covered the entire experimental unit. Constant water levels were maintained in the experimental ponds by supplying ground water periodically to compensate for loss due to evaporation. However, as the experiment was conducted during the rainy season, evaporation loss was minimal and was mostly replenished naturally by rainwater. Approximately $1000 \mathrm{~L}$ of excess water was discharged from the live food ponds (LF), everyday during the introduction of plankton water. A plankton cloth was tied over the outflow water pipe to prevent any loss of zooplankton during the process. In the control ponds, a commercial pellet diet (Tokyo pellets, Japan) containing $32 \%$ crude protein was added, based on the amount of $5 \%$ body weight of cultured fish, daily.

Water samples were collected weekly at a fixed hour of the day (9.00hour) as described earlier (Jha et al, 2004) and routine water quality parameters (dissolved oxygen or DO, biological oxygen demand or BOD, free $\mathrm{CO}_{2}$, alkalinity, $\mathrm{PO}_{4}-\mathrm{P}, \mathrm{NH}_{4}-\mathrm{N}, \mathrm{NO}_{2}-\mathrm{N}, \mathrm{NO}_{3}-\mathrm{N}$, and specific conductivity) were estimated according to methods as described by APHA (1998). Temperature was recorded using a mercury thermometer. The $\mathrm{pH}$ was measured in situ using a portable $\mathrm{pH}$ meter (Hanna Instruments). Sediment samples were collected weekly and the amounts of total nitrogen and organic carbon in the sediment and the manures used in the experiment were estimated according to Micro-Kjeldahl's method (Anderson \& Ingram, 1993) and Wet Oxidation method (Walkley \& Black, 1934), respectively. Samples of plankton were collected with a plankton net made of standard bolting silk cloth (No. 21 with $77 \mathrm{mesh} / \mathrm{cm}^{2}$ ), twice a week. Collected plankton samples were concentrated to $20 \mathrm{~mL}$ and preserved in $4 \%$ formalin. Enumeration of $1 \mathrm{~mL}$ of concentrated plankton was performed under a stereoscopic microscope using Sedgwick Rafter Counting Cell.

For bacteriological analysis, water samples were collected weekly in pre-sterilized glass bottles $(125 \mathrm{~mL})$, and processed within 6hrs of collection. Weekly sediment samples were collected by hand and stored in pre-sterilized plastic containers. The suspension of sediment was prepared by mixing $1 \mathrm{~g}$ of wet sediment in $99 \mathrm{~mL}$ of sterile distilled water. The aerobic heterotrophic bacteria were enumerated in nutrient agar by serial dilution of the sample, followed by the conventional spread plate method (Chen \& Kueh, 1976; Cappuccino \&
Sherman, 1992). Aeromonas sp. and Pseudomonas sp. were similarly enumerated on Aeromonas Isolation Medium Base and Pseudomonas Isolation Agar, respectively. All the bacteriological media were obtained from Himedia Laboratories Ltd., Mumbai, India. After inoculation, the Petri dishes containing the culture media were incubated at $37^{\circ} \mathrm{C}$ for $48 \mathrm{hrs}$. The populations of bacteria were expressed in terms of cfus./mL (colony forming units) in water, and cfus./g for the sediments. Arithmetical means from three Petri dishes for each dilution were used in the study.

The weights of the fish were recorded at the beginning of the experiment and during harvest to the nearest $0.001 \mathrm{~g}$. However, individual data could not be recorded from every harvested fish. In its place, 1000 fish were randomly selected from each pond and data was collected. For this the fish were anaesthetized with tricaine methene sulphonate (MS-222) of $0.4 \mathrm{~g} / \mathrm{L}$ concentration. Dead fish were removed daily, and were not replaced during the course of the study. Differences between the number of fish stocked and the number of fish at harvest were used to calculate mortality percentage in each treatment.

The specific growth rate (SGR) was calculated as: $\mathrm{SGR}=100\left[\left(\operatorname{lnW}_{\mathrm{t}}-\ln \mathrm{W}_{0}\right) / \mathrm{t}\right]$; where $\mathrm{W}_{0}$ and $\mathrm{W}_{\mathrm{t}}$ are the initial and final weights of live fish (g) respectively, and (t) is the culture period in days (Ricker, 1975). Fish growth and survival were assessed by one way analysis of variance (ANOVA) and where a significant difference $(P<0.05)$ was detected, Tukey's HSD test (Zar, 1999) was applied to compare and rank means.

\section{Results}

The amount of total nitrogen in cow and poultry manures was $2.12 \%$ and $2.59 \%$, respectively, and the amount of organic carbon was $22.06 \%$ and $28.52 \%$, respectively. Water temperature was between $22^{\circ} \mathrm{C}$ and $38^{\circ} \mathrm{C}$ during the 11 weeks. However, there was no difference in water temperature from one management regime to another on any particular sampling date. The water $\mathrm{pH}$ in all the treatments was neutral to acidic (Tab. 1). The values of free $\mathrm{CO}_{2}$ and total alkalinity were significantly higher in PM $(P<0.05)$, compared to the other treatments. Total alkalinity here refers to bicarbonate alkalinity, as carbonate was not present in the water of any management regime during the entire study period. Average $\mathrm{PO}_{4}-\mathrm{P}, \mathrm{NO}_{3}-\mathrm{N}, \mathrm{NO}_{2}-\mathrm{N}, \mathrm{NH}_{4}$ $-\mathrm{N}$, specific conductivity, and BOD were significantly higher $(P<0.05)$ in $\mathrm{PM}$ and $\mathrm{CD}$, compared to the $\mathrm{LF}$ and 
control treatments (Tab. 1). However, the values of dissolved oxygen were significantly higher $(P<0.05)$ in the LF treatment, than other treatments (Tab. 1). The range of recorded $\mathrm{pH}$ values was highest in the $\mathrm{LF}$ treatment (Tab. 1). Like water, the sediment $\mathrm{pH}$ was also highest $(P<0.05)$ in the LF treatment (Tab. 1). The percentage of organic carbon and total nitrogen in the pond sediments were highest in the PM treatment $P<0.05$ ), followed by the CD, C, and LF treatments, although the values in the latter two treatments were not significantly different $(P>0.05)$ from one another (Tab. 1).

Examination of plankton showed considerable differences in species diversity and abundance between different treatments. The cladocerans formed the most abundant group in LF, whereas copepods were more dominant in all the other treatments (Tab. 2). On average, total plankton volume (no./L) was highest in $\mathrm{LF}$, followed by $\mathrm{PM}, \mathrm{CD}$, and $\mathrm{C}$ treatments in decreasing order $(P<0.05)$. Plankton population in all the treatments was dominated by zooplankton. Average zooplankton abundance (no./L) also followed the same trend as the total plankton abundance and recorded highest in LF $(P<0.05)$ (Tab. 2). In contrast, average phytoplankton abundance (no./L) was significantly higher $(P<0.05)$ in the manure based treatments (PM and CD), compared to LF and C (Tab. 2).

Results of enumeration of heterotrophic bacterial populations showed a highly variable result among the four treatments. The average counts of heterotrophic bacteria in PM $\left(123.58 \times 10^{3} \mathrm{cfus} . / \mathrm{mL}\right)$ and $\mathrm{CD}(95.75 \times$ $10^{3}$ cfus./ $\left.\mathrm{mL}\right)$ was significantly higher $(P<0.05)$ than the LF and C treatments (Tab. 3). A marked difference in the mean counts of Aeromonas sp. and Pseudomonas sp. was also observed among the treatments (Tab. 3). Highest counts for both genera were observed in the PM treatment, followed in decreasing order by the CD and C treatments $(P<0.05)$. However, Aeromonas sp. and Pseudomonas sp. were absent from the water of LF ponds. In the pond sediments, there were no significant differences in the total aerobic heterotrophic counts between different treatments $(P>0.05)$ (Tab. 3). However, the Aeromonas and Pseudomonas bacterial counts of the pond sediments followed similar trends, as the pond water and the highest counts for both these genera were encountered in $\mathrm{PM}$, followed in decreasing abundance by the CD, C, and LF treatments $(P<0.05)$.

The final body weight of the koi carps ranged from $3.14 \mathrm{~g}$ to $9.64 \mathrm{~g}$ in the different treatments (Tab. 4). At harvest, maximum weight gain was achieved in the LF treatment, followed in decreasing order by PM, CD, and $\mathrm{C}$ treatments $(P<0.05)$. The specific growth rate (SGR) was quite high $(>4.0)$ in all the treatments, though the differences among the various treatments were significant $(P<0.05)$. There was a significant difference $(P<0.05)$ in the survival of koi carp among the treatments ranging from $67.21 \%(\mathrm{C})$ to $90.11 \%(\mathrm{LF})$.

Tab. 1 Mean $\pm S E$ of major physico-chemical parameters analyzed for water and bottom sediments of the four treatments. Each mean value represents the weekly data collected during the 11week growth period. Different superscripts in the same row indicate statistically significant differences between means at $\boldsymbol{P}<\mathbf{0 . 0 5}$. For $\mathbf{p H}$, the range of recorded values are presented

\begin{tabular}{|c|c|c|c|c|}
\hline \multirow{2}{*}{ Parameters } & \multicolumn{4}{|c|}{ Treatments } \\
\hline & LF & PM & $\mathrm{CD}$ & $\mathrm{C}$ \\
\hline & \multicolumn{4}{|c|}{ Water } \\
\hline $\mathrm{pH}$ & $6.3-7.7$ & $5.3-6.6$ & $5.6-6.8$ & $6.1-7.5$ \\
\hline Dissolved oxygen (mg/ L) & $6.63 \pm 0.28^{\mathrm{a}}$ & $5.45 \pm 0.25^{b}$ & $5.79 \pm 0.23^{\mathrm{ab}}$ & $6.35 \pm 0.30^{\mathrm{ab}}$ \\
\hline $\mathrm{BOD}(\mathrm{mg} / \mathrm{L})$ & $1.65 \pm 0.09^{b}$ & $4.22 \pm 0.47^{\mathrm{a}}$ & $3.30 \pm 0.31^{\mathrm{a}}$ & $1.85 \pm 0.15^{b}$ \\
\hline Free $\mathrm{CO}_{2}(\mathrm{mg} / \mathrm{L})$ & $2.08 \pm 0.10^{c}$ & $4.88 \pm 0.26^{\mathrm{a}}$ & $3.57 \pm 0.23^{b}$ & $2.37 \pm 0.10^{c}$ \\
\hline Total alkalinity (mg/ L) & $24.67 \pm 0.85^{c}$ & $72.22 \pm 4.27^{c}$ & $58.17 \pm 3.13^{b}$ & $29.90 \pm 0.97^{c}$ \\
\hline $\mathrm{PO}_{4}-\mathrm{P}(\mathrm{mg} / \mathrm{L})$ & $0.16 \pm 0.010^{b}$ & $0.69 \pm 0.083^{\mathrm{a}}$ & $0.51 \pm 0.059^{\mathrm{a}}$ & $0.21 \pm 0.017^{b}$ \\
\hline $\mathrm{NH}_{4}-\mathrm{N}(\mathrm{mg} / \mathrm{L})$ & $0.161 \pm 0.011^{\mathrm{b}}$ & $0.569 \pm 0.064^{\mathrm{a}}$ & $0.514 \pm 0.048^{\mathrm{a}}$ & $0.203 \pm 0.014^{b}$ \\
\hline $\mathrm{NO}_{2}-\mathrm{N}(\mathrm{mg} / \mathrm{L})$ & $0.006 \pm 0.001^{\mathrm{b}}$ & $0.047 \pm 0.006^{\mathrm{a}}$ & $0.038 \pm 0.004^{\mathrm{a}}$ & $0.007 \pm 0.001^{b}$ \\
\hline $\mathrm{NO}_{3}-\mathrm{N}(\mathrm{mg} / \mathrm{L})$ & $0.121 \pm 0.007^{\mathrm{b}}$ & $0.462 \pm 0.053^{\mathrm{a}}$ & $0.380 \pm 0.046^{\mathrm{a}}$ & $0.148 \pm 0.013^{b}$ \\
\hline \multirow[t]{2}{*}{ Specific conductivity (mmhos/ cm) } & $0.305 \pm 0.012^{b}$ & $0.711 \pm 0.078^{\mathrm{a}}$ & $0.606 \pm 0.070^{\mathrm{a}}$ & $0.364 \pm 0.025^{b}$ \\
\hline & \multicolumn{4}{|c|}{ Sediment } \\
\hline $\mathrm{pH}$ & $5.2-6.8$ & $4.6-5.9$ & $4.5-5.8$ & $5.0-6.8$ \\
\hline Organic C (\%) & $1.27^{\mathrm{c}}$ & $2.94^{\mathrm{a}}$ & $2.02^{b}$ & $1.32^{\mathrm{c}}$ \\
\hline Total N (\%) & $0.093^{c}$ & $0.260^{\mathrm{a}}$ & $0.215^{\mathrm{b}}$ & $0.116^{c}$ \\
\hline
\end{tabular}


Tab. 2 Species composition, abundance (no./L) and relative abundance (\% of total numbers) of plankton in experimental ponds maintained under different management regimes. Each mean value represents data from 22 samples collected twice a week during the 11-week growth period

\begin{tabular}{|c|c|c|c|c|c|c|c|c|}
\hline \multirow{2}{*}{ Species } & \multicolumn{2}{|c|}{$\mathrm{LF}$} & \multicolumn{2}{|c|}{$\mathrm{PM}$} & \multicolumn{2}{|c|}{$\mathrm{CD}$} & \multicolumn{2}{|c|}{$\mathrm{C}$} \\
\hline & (no./L) & $(\%)$ & (no./ L) & $(\%)$ & (no./L) & $(\%)$ & (no./L) & $(\%)$ \\
\hline Chlorella sp. & 56.91 & 3.51 & 48.32 & 3.39 & 46.19 & 3.75 & 17.23 & 6.25 \\
\hline Navicula sp. & 58.13 & 3.58 & 72.38 & 5.08 & 61.95 & 5.03 & 20.69 & 7.51 \\
\hline Spirogyra sp. & 3.71 & 0.23 & 38.15 & 2.68 & 42.21 & 3.43 & 5.61 & 2.03 \\
\hline Scenedesmus sp. & 1.04 & 0.06 & 18.24 & 1.28 & 16.18 & 1.31 & 3.02 & 1.09 \\
\hline Phacus sp. & 21.20 & 1.30 & 29.16 & 2.05 & 39.20 & 3.18 & 3.16 & 1.15 \\
\hline Synedra sp. & 1.13 & 0.07 & 25.86 & 1.81 & 14.12 & 1.15 & 5.29 & 1.93 \\
\hline Phytoplankton & 142.12 & 8.75 & 232.11 & 16.29 & 219.85 & 17.85 & 55.00 & 19.96 \\
\hline Daphnia sp. & 274.38 & 16.90 & 168.13 & 11.80 & 122.64 & 9.96 & 5.26 & 1.91 \\
\hline Moina sp. & 306.34 & 18.87 & 198.70 & 13.95 & 133.06 & 10.81 & 15.11 & 5.48 \\
\hline Bosmina sp. & 108.26 & 6.67 & 81.43 & 5.72 & 64.19 & 5.21 & 3.20 & 1.16 \\
\hline Cladocera & 688.98 & 42.44 & 448.26 & 31.47 & 319.89 & 25.98 & 23.57 & 8.55 \\
\hline Cyclops sp. & 281.65 & 17.35 & 261.91 & 18.39 & 254.20 & 20.64 & 72.77 & 26.41 \\
\hline Diaptomus sp. & 262.80 & 16.19 & 235.28 & 16.52 & 208.05 & 16.89 & 59.10 & 21.45 \\
\hline Nauplii & 86.14 & 5.30 & 105.38 & 7.40 & 95.49 & 7.75 & 42.34 & 15.36 \\
\hline Copepoda & 630.59 & 38.84 & 602.57 & 42.31 & 557.74 & 45.29 & 174.21 & 63.22 \\
\hline Brachionus sp. & 55.14 & 3.39 & 58.90 & 4.13 & 62.34 & 5.06 & 10.29 & 3.73 \\
\hline Keratella sp. & 106.62 & 6.57 & 82.42 & 5.79 & 71.53 & 5.81 & 12.48 & 4.53 \\
\hline Rotifera & 161.76 & 9.96 & 141.32 & 9.92 & 133.86 & 10.87 & 22.77 & 8.26 \\
\hline Zooplankton & 1481.33 & 91.25 & 1192.15 & 83.71 & 1011.49 & 82.15 & 220.55 & 80.04 \\
\hline Total Plankton & 1623.45 & - & 1424.26 & - & 1231.34 & - & 275.55 & - \\
\hline
\end{tabular}

Tab. 3 Abundance of total heterotrophic bacteria, Aeromonas sp. and Pseudomonas sp. in the water and bottom sediment analyzed for the four treatments. Each mean value represents weekly data collected during the 11-week growth period. Different superscripts in the same row indicate statistically significant differences between means at $P<0.05$

\begin{tabular}{|c|c|c|c|c|}
\hline & \multicolumn{4}{|c|}{ Treatments } \\
\hline & $\mathrm{LF}$ & PM & $\mathrm{CD}$ & $\mathrm{C}$ \\
\hline & \multicolumn{4}{|c|}{ Water } \\
\hline Total heterotrophic bacteria (cfus $\times 10^{3} / \mathrm{mL}$ ) & $17.08^{\mathrm{b}}$ & $123.58^{\mathrm{a}}$ & $95.75^{\mathrm{a}}$ & $28.17^{b}$ \\
\hline Aeromonas sp.(cfus./ mL) & - & $3.63^{a}$ & $2.01^{\mathrm{b}}$ & $1.08^{\mathrm{c}}$ \\
\hline \multirow[t]{2}{*}{ Pseudomonas sp.(cfus./ mL) } & - & $2.10^{a}$ & $1.29^{b}$ & + \\
\hline & \multicolumn{4}{|c|}{ Sediment } \\
\hline Total heterotrophic bacteria (cfus×10 $10^{5}$ g) & $32.42^{a}$ & $38.12^{a}$ & $36.28^{a}$ & $38.10^{\mathrm{a}}$ \\
\hline Aeromonas sp. (cfus./g) & + & $13.88^{\mathrm{a}}$ & $10.21^{b}$ & $4.28^{c}$ \\
\hline Pseudomonas sp. (cfus./g) & + & $9.04^{\mathrm{a}}$ & $7.19^{b}$ & $3.76^{c}$ \\
\hline
\end{tabular}

$+=<1.0$; - = absent.

Tab. 4 Mean $\pm S E$ of growth parameters recorded for koi carp reared in earthen ponds (2 June-18 August, 2004) under different management regimes. Different superscripts in the same row indicate statistically significant differences between means at $\boldsymbol{P}<\mathbf{0 . 0 5}$

\begin{tabular}{lrrrr}
\hline & \multicolumn{4}{c}{ Treatment } \\
\cline { 2 - 5 } & \multicolumn{1}{c}{ LF } & PM & CD & C \\
\hline Harvest weight (g) & $9.64 \pm 0.28^{\mathrm{a}}$ & $6.83 \pm 0.21^{\mathrm{b}}$ & $4.17 \pm 0.15^{\mathrm{c}}$ & $3.14 \pm 0.18^{\mathrm{d}}$ \\
Weight gain (g) & $9.51 \pm 0.28^{\mathrm{a}}$ & $6.70 \pm 0.21^{\mathrm{b}}$ & $4.04 \pm 0.15^{\mathrm{c}}$ & $3.01 \pm 0.18^{\mathrm{d}}$ \\
SGR (\%/day) & $5.58 \pm 0.14^{\mathrm{a}}$ & $5.14 \pm 0.09^{\mathrm{b}}$ & $4.51 \pm 0.10^{\mathrm{c}}$ & $4.13 \pm 0.04^{\mathrm{d}}$ \\
Survival rate (\%) & $90.11 \pm 0.61^{\mathrm{a}}$ & $84.50 \pm 0.19^{\mathrm{a}}$ & $78.18 \pm 0.38^{\mathrm{b}}$ & $67.21 \pm 0.45^{\mathrm{c}}$ \\
\hline
\end{tabular}




\section{Discussion}

The microbiological status of the water in which fish culture takes place depends on a wide variety of factors influencing the environment, the most important being the organic matter content (Rheinheimer, 1980; Sugita et al, 1985b; Zmyslowska et al, 2003). Variations in the abundance of heterotrophic bacteria in the water samples of the four treatments were the result of differences in management practices resulting in different organic loads in the pond system. Thus the management regimes receiving organic manures (PM and $\mathrm{CD}$ ) recorded significantly higher populations of total heterotrophic bacteria $(P<0.05)$, compared to other treatments (Tab. 3). The highly productive nature of the manured ponds was also supported by the greater abundance (no./L) of total plankton, compared to the control treatment (Tab. 2).

Lower counts of heterotrophic bacteria in control ponds not receiving any organic manuring have been reported earlier by many authors (Barat \& Jana, 1990; Jana \& De, 1990; Barik et al, 2001; Majumdar et al, 2002). As such, the control system appeared to be less productive, indicated from the significantly lower plankton abundance $(P<0.05)$, compared to the manured treatments (Tab. 2). According to Ludwig (1999), when organic fertilizers are added to a pond, they are decomposed by bacteria and the water rapidly gains nutrients from the bottom. The released nutrients are rapidly utilized by phytoplankton and other bacteria, which are simultaneously grazed by single cell protozoan and other zooplankton. In control ponds, as also observed in our study, there are few nutrients, and hence few living organisms.

Although heterotrophic bacteria and phytoplankton are important components in the cycle of organic matter and inorganic nutrients in aquatic ecosystems, they may affect each other positively or negatively, depending on the nutrient conditions of their environment (Wang \& Priscu, 1994; Kamjunke et al, 1997; Duvall et al, 2001). Because bacteria have a high surface area to volume ratio (Currie \& Kalff, 1984), it has been suggested that bacteria should be superior competitors with phytoplankton for nitrogen and phosphorus (Elser et al, 1995). However, in our experiment, higher abundances of heterotrophic bacteria in manured treatments correlated with high phytoplankton abundance (in PM, $r=0.625 ; P<0.01$; in CD, $r=0.588 ; P<0.01$ ).
Brett et al (1999) suggested that the underlying mechanisms behind the positive correlation between phytoplankton and bacteria are tangled in complex interactions between factors such as inorganic nutrient concentrations, organic nutrient availability, protozoan bactivory, availability of physical substrate, as well as light and temperature. Such complications could prevent augmented bacterial populations from having significant effects on phytoplankton. In experiments by Cottingham et al (1997), bacteria did not buffer phytoplankton responses to nutrient enrichment. In view of the continuous grazing pressure on bacteria and phytoplankton by zooplankton and on zooplankton by fish larvae, it is very difficult to estimate the exact population density of bacteria, phytoplankton or zooplankton in any aquatic system. However, the overall results clearly demonstrate the importance of pond management on the growth responses of heterotrophic bacteria.

The abundance of heterotrophic bacteria in the pond sediments did not differ from one system to another (Tab. 3). This implies that the sediment in all fish ponds in our experiment, regardless of the farming system, contained the optimal amount of essential nutrients necessary for rapid growth of heterotrophic bacteria. Jana \& De (1990) obtained similar results in the sediment of traditional and manure treated ponds. According to Jinyi et al (1988), because of the sedimentation of applied manure and pond mud in both manure-applied and controlled ponds, the amount of bacteria in the water column decreases between the bottom of the pond and the surface layer of water with the continuous release of microorganism from the sediments. Similar results were obtained in our study (Tab. 3).

Greater abundance of Aeromonas sp. and Pseudomonas sp. in the water and sediments of PM and $\mathrm{CD}$, compared to the control treatment, indicate their sewage character. Very high counts of Aeromonas sp. and Pseudomonas sp. in ponds manured with animal excreta have been reported by many authors (Cloete et al, 1984; Jinyi et al, 1987; Jinyi et al, 1988; Hamza et al, 1998) The introduction of live plankton in the LF treatment, however, significantly reduced the population of total heterotrophic bacteria, as well as Aeromonas and Pseudomonas in both water and sediment, compared to the manured treatments (Tab. 3). 
The water quality was also influenced by the management conditions. Significantly high $\mathrm{NH}_{4}-\mathrm{N}$ in the PM and CD treatments could be related to the greater abundance of heterotrophic bacteria in these treatments, apart from ammonifying bacteria, which was not enumerated in our experiment, many heterotrophic bacteria are known to utilize nitrogen-rich substrates and release ammonia or ammonium salts (Jana \& Barat, 1983). Yao \& Zhaoyang (1997) reported that the contact layer between pond mud surface and water is the major source of nutrition. The organic nitrogen decomposed to $\mathrm{NH}_{4}-\mathrm{N}$ by bacterial activity adheres to the surface of the mud before being released in the water where it continuously rises to the surface of the water and escapes into the air (Blackburn \& Henriksen, 1983; Mei et al, 1995).

Depletion of dissolved oxygen after manure application often leads to heterotrophic organisms in the water utilizing $\mathrm{NO}_{3}-\mathrm{N}$ as electron receptors instead of oxygen, thus converting it to nitrite (Boyd, 1990). Higher concentration of BOD, $\mathrm{NH}_{4}-\mathrm{N}, \mathrm{NO}_{2}-\mathrm{N}$ and other nutrients, along with the higher counts of Aeromonas sp. and Pseudomonas sp. in the manure treated culture regimes may have lowered the grazing activity by the carp, compared to the LF treatment. Neutral to acidic $\mathrm{pH}$ in the water of a majority of the treatments (Tab. 1) could be related to the acidic nature of water bodies in North Bengal (Nath et al, 1994; Jha \& Barat, 2003; Jha et al, 2003). Lower range of $\mathrm{pH}$ values in the $\mathrm{PM}$ and CD ponds could be attributed to the animal manure applied in these treatments (Jha et al, 2004; Jha et al, 2006; Jha et al, 2007).

Zooplankton is required as a first food for most cultured fish (Ludwig, 1999). In an earlier experiment, a direct correlation $(r=0.957 ; \quad P<0.05)$ was observed between the weight gain of koi carp and the amount of zooplankton present in tanks under different doses of organic manuring (Jha et al, 2004). The maximum concentration of zooplankton in the LF treatment could be the consequence of improved water quality, expressed in terms of lower values of BOD, $\mathrm{NH}_{4}-\mathrm{N}$ and $\mathrm{NO}_{2}-\mathrm{N}$, and higher values of dissolved oxygen, which is conducive to fast reproduction of some of the major zooplankton constituting the main food item of carps (Jana \& Chakrabarti, 1993), and also due to the regular introduction of plankton.

Higher weight gain and survival rate of koi carp in the LF treatment could be attributed to better water quality (Tab. 1) in that treatment (Jha \& Barat, 2005c).
Again, the differences in the weight gain of koi carp observed among the different treatments were not essentially due to changes in the water quality, since, weight gain in the $\mathrm{C}$ treatment was lower than $\mathrm{PM}$ and CD treatments $P<0.05$ ), despite having better water quality. It might well be that the weight gain was more directly related to the differences in food concentration, although the zooplankton concentration and water quality were closely related to each other.

All aquaculture production systems must provide a suitable environment to promote the growth of aquatic crops. Although application of organic manure does not directly cause bacterial diseases in fish, the significantly greater abundance of pathogenic bacteria (Aeromonas sp. and Pseudomonas sp.) in the water and sediments of the manured treatments (PM and CD) could lead to diseases. Should fish resistance to disease be low, the possibility of occurrence of bacterial disease is higher in these treatments. Therefore, proper pond management should be observed to prevent any chance of bacterial disease.

Though it has been established that high fish yield in culture systems can be achieved by higher abundance of plankton through organic manuring, practical alternatives to pond manuring are needed because manuring may reduce water quality. Intensive stocking of ornamental fish ponds in India requires a standard water quality to be maintained throughout, so that fish growth is not adversely affected. In view of the financial constraints of marginal farmers who cannot afford modern aeration or waste-treatment equipments, raising of ornamental carp larvae in ponds fed exogenously with zooplankton is of considerable significance because not only would such feeding support high rates of survival and production, it would also maintain greater abundance of zooplankton in the system and better water quality with lower concentrations of Aeromonas sp. and Pseudomonas sp. in the system.

Acknowledgment : We wish to express our gratitude to Dr Wurts WA, Kentucky State University, Princeton, United States, and Dr Pekar F, HAKI, Szarvas, Hungary, for their suggestions and critical comments on the research plan. The first author is also grateful to Dr Das BK, and Mr Samal SK, both from Central Institute of Freshwater Aquaculture (CIFA), Bhubaneshwar, India, for their help in standardizing some of the microbiological analysis, and Dr Pradhan BP, Department of Chemistry, North Bengal University, for guiding the physico-chemical analysis of sediment 
samples. Mrs Patri P, and Mrs Kumari J, both from CIFA, provided useful literature assistance. Mr Sarkar K, owner

\section{References:}

Anderson JM, Ingram JSI. 1993. Soil organic matter and organic carbon [A]. In: Anderson JM, Ingram JSI. Tropical Soil Biology and Fertility [M]. Wallingford: CAB International, 62-66.

Ansa EJ, Jiya J. 2002. Effects of pig manure on the growth rate of Oreochromis niloticus under integrated fish cum pig farming system [J]. Journal of Aquatic Sciences, 17: 85-88.

APHA. 1998. Standard Methods for the Examination of Water and Wastewater [C]. 20 ${ }^{\text {th }}$ Edition. Washington: American Public Health Association, American Water Works Association, and Water Pollution Control Federation.

Barat S, Jana BB. 1990. Density differences of heterotrophic bacteria of water between carnivorous catfish farming and polyculture system of herbivorous carps [A]. In: Manna GK, Jana BB. Impacts of Environment on Animals and Aquaculture [M]. Kalyani: University of Kalyani, 207-214.

Barik SK, Purushothaman CS, Mohanty AN. 2001. Phosphatase activity with reference to bacteria and phosphorus in tropical freshwater aquaculture pond systems [J]. Aquaculture Research, 32: 819-832.

Blackburn TH, Henriksen K. 1983. Nitrogen cycling in different types of sediments from Danish waters [J]. Limnology and Oceanography, 28: 477-493.

Boyd CE. 1982. Water Quality Management in Pond Fish Culture [M]. Amsterdam: Elsevier Scientific Publishing Company, BV.

Boyd CE. 1990. Water Quality in Ponds for Aquaculture [M]. Alabama: Birmingham Publishing Company.

Brett MT, Lubnow FS, Villar-Argaiz M, Muller-Solger A, Goldman CR. 1999. Nutrient control of bacterioplankton and phytoplankton dynamics [J]. Aquatic Ecology, 33: 1-1.

Cappuccino JG, Sherman N. 1992. Microbiology [M]. California: The Benjamin/ Cummings Publishing Company, Inc.

Chen KY, Kueh SW. 1976. Distribution of heterotrophic bacteria related to some environmental factors in Tolo harbour [J]. International Journal of Ecology and Environmental Sciences, 1: 47-58.

Cloete TE, Toerien DF, Pieterse AJH. 1984. The bacteriological quality of water and fish of a pond system for the treatment of cattle feedlot effluent [J]. Agricultural Wastes, 9: 1-15.

Cottingham KL, Knight SE, Carpenter SR, Cole JJ, Pace ML, Wagner AE. 1997. Responses of phytoplankton and bacteria to nutrients and zooplankton: a mesocosm experiment [J]. Journal of Plankton Research, 19: 995-1010.

Currie DJ, Kalff J. 1984. A comparison of the abilities of freshwater algae and bacteria to aquire and retain phosphorus [J]. Limnology and Oceanography, 29: 298-310.

Das BK. 2004. Bacterial diseases of fish and their control [A]. In: Swain P, Sahoo PK, Das BK. Disease Diagnosis and Health Management of Freshwater Fish and Shellfish [M]. Bhubaneshwar: Central Institute of Freshwater Aquaculture, 45-52.

Duvall RJ, Anderson LJW, Goldman CR. 2001. Pond enclosure evaluations of microbial products and chemical algicides used in lake management [J]. Journal of Aquatic Plant Management, 39: 9-106.

Elser JJ, Stabler LB, Hassett RP. 1995. Nutrient limitation of bacterial growth and rates of bacterivory in lakes and oceans: a comparative study [J]. Aquatic Microbial Ecology, 9: 105-110.

Hamza AK, Hala HA, Hoda HY. 1998. Fish farming management studies on quantitative and qualitative bacterial microflora of fish reared in a of Rainbow Ornamental Fish Farm, Jalpaiguri, India, assisted during the field experiments. brakish water fish farm in Alexandria, Egypt [J]. Acta Hydrobiologica, 40: $1-8$.

Hojovec J. 1977. Health effects from waste utilization [A]. In: Taiganides EP. Animal Wastes [M]. London: Applied Science Publishers Limited, 105-109.

Jana BB, Barat S. 1983. Development of heterotrophic and ammonifying bacterial populations as affected by the fish Clarias batrachus (Linn.) under different experimental conditions [J]. Acta Hydrochimica et Hydrobiologica, 5: 569-576.

Jana BB, De UK. 1990. Spatial and seasonal distribution of heterotrophic bacteria in pond water and sediments under different management practices [J]. International Revue der Gesamten Hydrobiologie, 75: 639-648.

Jana BB, Chakrabarti R. 1993. Life table responses of zooplankton (Moina micrura Kurz and Daphnia carinata King) to manure application in a culture system [J]. Aquaculture, 117: 274-285.

Jana BB, Chatterjee J, Ganguly S, Jana T. 2001. Responses of phosphate solubilizing bacteria to qualitatively different fertilization in simulated and natural fish ponds [J]. Aquaculture International, 9: 17-34.

Jha P, Barat S. 2003. Hydrobiological study of lake Mirik in Darjeeling Himalayas [J]. Journal of Environmental Biology, 24: 339-344.

Jha P, Barat S. 2005a. Management induced changes in food selection, growth and survival of koi carp, Cyprinus carpio var. koi L., in tropical ponds [J]. Israeli Journal of Aquaculture / Bamidgeh, 57: 115-124.

Jha P, Barat S. 2005b. The effect of different stocking density on growth, survival rate, and number of marketable fish produced of koi carps, Cyprinus carpio vr. koi, in concrete tanks [J]. Journal of Applied Aquaculture, 17: 89-102.

Jha P, Barat S. 2005c. Effect of water exchange on water quality and the production of ornamental carp (Cyprinus carpio var. koi L.) cultured in concrete tanks manured with poultry excreta [J]. Archives of Polish Fisheries, 13: 77-90.

Jha P, Barat S, Lepcha RF. 2003. A comparative study of limnochemistry and primary productivity of some fish ponds in the northern districts of West Bengal, India [J]. Ecology, Environment and Conservation, 9: 135-140.

Jha P, Sarkar K, Barat S. 2004. Effect of different application rates of cowdung and poultry excreta on water quality and growth of ornamental carp, Cyprinus carpio vr. koi, in concrete tanks [J]. Turkish Journal of Fisheries and Aquatic Sciences, 4: 17-22.

Jha P, Barat S, Nayak CR. 2006. A comparison of growth, survival rate and number of marketable koi carp produced under different management regimes in earthen ponds and concrete tanks [J]. Aquaculture International, 14: 615-626.

Jha P, Barat S, Sarkar K. 2007. Comparative effect of live-food and manured treatments on water quality and production of ornamental carp, Cyprinus carpio var. koi L., during winter, summer, monsoon and post monsoon growout experiments in concrete tanks [J]. Journal of Applied Ichthyology, 23: 87-92.

Jinyi D, Xianzhen G, Xiuzhen F, Meizhen L. 1987. Preliminary studies on the effects of animal manure on bacterial disease of fish [M]. NACA Working Paper No. 49. Bangkok: Network of Aquaculture Centres in Asia-Pacific.

Jinyi D, Xianzhen G, Xiuzhen F, Meizhen L, Zhang W. 1988. Preliminary studies on the effect of live stock manure application on bacterial fish 
disease and human hygene [M]. NACA Working Paper No. 69. Bangkok: Network of Aquaculture Centres in Asia-Pacific.

Kadri MO, Emmanuel D. 2003. Growth of phytoplankton in different fertilizer media [J]. Journal of Aquatic Sciences, 18: 15-19.

Kamjunke N, Boing W, Voigt H. 1997. Bacterial and primary production under hypertrophic conditions [J]. Aquatic Microbial Ecology, 13: 2935.

Ludwig GM. 1999. Zooplankton succession and larval fish culture in freshwater ponds [M]. SRAC Publication No. 700. Stoneville: Southern Regional Aquaculture Center, Mississippi State University.

Majumdar S, Biswas S, Barat S. 2002. Abundance of ammonifying and heterotrophic bacterial populations in the water manured with cowdung and distillery sludge in outdoor model tanks [J]. Asian Journal of Microbiology, Biotechnology and Environmental Science, 4: 229-233.

Mei Z, Shi Z, Zhu X. 1995. The studies on the nutritional content and the release of the fish pond mud [A]. In: Zhu X, Shi Z. The Studies of the Ecosystem in the Chinese Fish Ponds [M]. Sanghai: Sanghai Science and Technology Press, 29-36.

Moriarty DJW. 1987. Methodology for determining biomass and productivity of microorganisms in detrital food webs [A]. In: Moriarty DJW, Pullin RSV. Detritus and Microbial Ecology in Aquaculture [M]. Manila: International Centre for Living Aquatic Resources Management, 4-31.

Nath D, Mandal LN, Tripathi SD, Karmakar HC. 1994. Correlation between fish production and physico-chemical parameters of water and soil in semi-intensive carp culture ponds of West Bengal, India [J]. Journal of the Inland Fisheries Society of India, 26: 106-115.

Parker NC. 1986. Stress and its implications in cultured fishes [A]. In: Grimaldi E, Rosenthal H. Trends and Problems in Aquacultural Development - Proceedings of the Second International Conference on Aquafarming - Aquaculture 84 [M]. Verona: Fiere di Verona, 167-177.

Quines OD. 1988. Microorganisms: indicator of pollution in integrated livestock-fish farming systems [J]. Environmental International, 14: 531-534.
Rheinheimer G. 1980. Aquatic Microbiology [M]. New York: John Wiley and Sons Limited.

Ricker WE. 1975. Computation and interpretation of biological statistics of fish populations [J]. Bulletin of the Fisheries Research Board of Canada, 191: 1-382.

Schroeder GL. 1987. Carbon pathways in aquatic detrital systems [A]. In: Moriarty DJW, Pullin RSV. Detritus and Microbial Ecology in Aquaculture [M]. Manila: International Centre for Living Aquatic Resources Management, 217-236.

Sugita H, Fushino T, Oshima K, Deguchi Y. 1985a. Microflora in the water and sediment of freshwater culture ponds [J]. Bulletin of the Japanese Society for Scientific Fisheries, 51: 91-97.

Sugita H, Ushioka S, Kihara D, Deguchi Y. 1985b. Changes in the bacterial composition of water of carp rearing tank [J]. Aquaculture, 44: 243247.

Walkley A, Black IA. 1934. An examination of the Degtjareff method for determining soil organic matter and prepared modifications of the chromic acid titration method [J]. Soil Science, 34: 29-38.

Wang L, Priscu JC. 1994. Influence of phytoplankton on the response of bacterioplankton growth to nutrient enrichment [J]. Freshwater Biology, 31: 183-190.

Wurts WA. 2000. Sustainable aquaculture in the twenty first century [J]. Reviews in Fisheries Science, 8: 141-150.

Yao S, Zhaoyang H. 1997. Shrimp pond settlement - the quantity of nutrients dispersion and seasonal changes between water and mud contracting surfaces [J]. Marine Fishery Research, 18: 60-66.

Zar JH. 1999. Biostatistical Analysis [M]. $4^{\text {th }}$ Edition. New Jersey: Prentice Hall International Inc.

Zmyslowska I, Kolman R, Krause J. 2003. Bacteriological evaluation of water, feed and sturgeon (Acipenser baeri Brandt) fry quality during intensive rearing in cooling water [J]. Archives of Polish Fisheries, 11: 91-98. 